\title{
Emotion and the affective turn: Towards an integration of cognition and affect in real life experience
}

\begin{tabular}{|c|c|}
\hline $\begin{array}{l}\text { Author: } \\
\text { Cornel W. du T }\end{array}$ & \\
\hline $\begin{array}{l}\text { Affiliation: } \\
{ }^{1} \text { Research Inst } \\
\text { Theology and } \\
\text { University of S } \\
\text { South Africa }\end{array}$ & $\begin{array}{l}\text { itute for } \\
\text { Religion, } \\
\text { outh Africa, }\end{array}$ \\
\hline $\begin{array}{l}\text { Note: } \\
\text { Prof. Cornel du } \\
\text { of the Researc } \\
\text { for Theology a } \\
\text { University of S } \\
\text { Pretoria, Sout }\end{array}$ & $\begin{array}{l}\text { Toit is head } \\
\text { Institute } \\
\text { nd Religion, } \\
\text { outh Africa, } \\
\text { Africa. }\end{array}$ \\
\hline $\begin{array}{l}\text { Corresponden } \\
\text { Cornel du Toit }\end{array}$ & Ice to: \\
\hline $\begin{array}{l}\text { Email: } \\
\text { dtoitcw@unis }\end{array}$ & a.ac.za \\
\hline $\begin{array}{l}\text { Postal addres } \\
\text { PO Box 392, U } \\
\text { South Africa, } \\
\text { South Africa }\end{array}$ & $\begin{array}{l}\text { niversity of } \\
\text { Pretoria } 0003,\end{array}$ \\
\hline $\begin{array}{l}\text { Dates: } \\
\text { Received: } 16 \text { A } \\
\text { Accepted: } 14 \\
\text { Published: } 20\end{array}$ & $\begin{array}{l}\text { pr. } 2014 \\
\text { lune } 2014 \\
\text { Nov. } 2014\end{array}$ \\
\hline $\begin{array}{l}\text { How to cite th } \\
\text { Du Toit, C.W., } \\
\text { and the affect } \\
\text { Towards an int } \\
\text { of cognition ar } \\
\text { in real life exp } \\
\text { HTS Toelogies } \\
\text { Theological St } \\
\text { Art. \#2692, } 9 \\
\text { http://dx.doi.c } \\
\text { hts.v70i1.2692 }\end{array}$ & $\begin{array}{l}\text { is article: } \\
\text { 2014, 'Emotion } \\
\text { ive turn: } \\
\text { tegration } \\
\text { d affect } \\
\text { erience', } \\
\text { e Studies/ } \\
\text { udies 70(1), } \\
\text { pages. } \\
\text { rg/10.4102/ }\end{array}$ \\
\hline $\begin{array}{l}\text { Copyright: } \\
\text { (C) 2014. The A } \\
\text { Licensee: AOS } \\
\text { OpenJournals. } \\
\text { is licensed unc } \\
\text { Creative Comr } \\
\text { Attribution Lic }\end{array}$ & $\begin{array}{l}\text { Iuthors. } \\
\text { IS } \\
\text { This work } \\
\text { der the } \\
\text { nons } \\
\text { ense. }\end{array}$ \\
\hline Read online: & \\
\hline 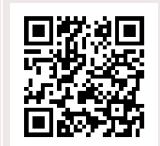 & $\begin{array}{l}\text { Scan this QR } \\
\text { code with your } \\
\text { smart phone or } \\
\text { mobile device } \\
\text { to read online. }\end{array}$ \\
\hline
\end{tabular}

Emotion is caused by many factors, some of which are evolutionary, neurological, chemical, environmental, societal, personal and religious. Mostly, however, we are oblivious of the causal factors, many of which may function on a biological level or subconsciously, although the emotional effect is experienced physically and consciously. Emotions change as the trigger mechanisms in the cultural context change. This usually happens unnoticed over long periods. Internet databases have now made it possible to study the use of emotive words; this point is discussed. Of particular interest is the interaction between emotion and reason. Models that reduce emotion to the physical level are scrutinised critically. Reason is not emotionless and emotion is not always irrational. The close interrelationship of emotion and reason often makes it difficult to distinguish accurately between the two. The so-called affective turn takes cognisance of cultural, social, religious and other environmental factors; this broader approach clarifies the importance of affect's role in rationality. One way of viewing emotion and affect is to look at the accompanying language; here the role of metaphor and narrative is pertinent. The traditional elevation of reason above emotion is examined critically as part of the affective turn that broadens the meaning and scope of emotions. I focus on the role of emotion in religion and factors that influence it, and explore the accent of affect in new spiritualities.

\section{Introduction}

Are we living in a post-emotional era ${ }^{1}$, post-emotional in the sense that little remains of emotional expressions such as those that once featured in purely evolutionary survival strategies? Emotions have come to be controlled pharmaceutically, reduced to 'stress' in everyday life, religiously contaminated, artificially induced by the entertainment industry, and virtually displaced in the cyber-world. Yet the notion of post-emotionality is misleading - it would be tantamount to posthumanity. What is undeniable is that the factors that evoke emotion and emotional behaviour as such have been changing throughout history.

Modernity has put the accent on rationality with little or no regard for emotion. Postmodernity focuses on the body, emotion and experience. In such a context, one would expect a pro-affective bias, but so far there is little sign of that.

Do new techniques and developments in cognitive and brain research (including more accurate measurement of localised brain activity ${ }^{2}$ ) help us to understand our emotional and affective side? Long before the advent of the neurosciences, valuable insights were proffered by philosophers (Aristotle, Descartes, Spinoza, Hume), psychologists (Freud, James) and sociologists (Weber), to mention a few such. ${ }^{3}$

Causality is a common denominator in the history of reflection on emotion. A key challenge is to determine exactly what governs emotion in each instance, the role of evolution, the brain, the body, the unconscious, the environment, language and the like. But direct, unequivocal causality is not easily demonstrable, and our understanding of emergent processes appears to be a better framework for fathoming emotion.

In July 1518, a 'dancing plague' broke out in the city of Strasbourg. A certain Frau Troffea, in a frenzied state, started dancing in the street. She continued for about six days. Within a week,

\footnotetext{
1.Technological progress has helped us to vanquish the unknown, the darkness of ignorance and superstition. Yet many see it as a loss and a reason for the disenchantment of the world. Walton (2004:15) points out that superstition and the supernatural appeal to many people. The possibility of a visit by a messenger from the spirit world is attractive rather than terrifying 'in order to feel the delicious thrill of terror'. Many people depend on the contrived emotions of others (reality television, soap opera TV series etc.). Experiencing emotions by vicarious make-believe fashion is their sole access to something like real life. Their lives are so predictable and dull that there is no emotional stimulation worth mentioning (Riis \& Woodhead 2010:183). Besides, we live in a culture that demands that we
be happy and enjoy life.

2.Concerning actual brain operation, research goes beyond the mere identification of areas of neurological activity: 'What we are beginning to learn is that there are perhaps no clear-cut zones but a process of negotiation and emergence' (Wetherell 2012:45).
}

3.See Darwin's Treatise on the passions, Hobbes's Leviathan, Spinoza's Ethics, Hume's Treatise. 
34 others had joined her, and within a month there were about 400 dancers. Some of them eventually succumbed to heart attack, stroke or exhaustion. Historical documents, including physicians' notes, cathedral sermons, local and regional chronicles, and even notes issued by the Strasbourg city council, make it clear that they had literally danced themselves to death. It is not known why these people took to dancing. It was a time of famine, disease and general hardship - enough to drive people to any extreme in order to escape. Was the dancing plague an involuntary emotional 'intervention' to free themselves from grim circumstances via the allure of uninterrupted dancing? (see Waller 2008).

For all its weird, paradoxical tragedy, the story does have a certain magical quality. Why use this example to clarify emotion? Dancing symbolises joy and vitality and in no way expresses despair or surrender. It is like bursting into laughter, instead of crying, when calamity strikes. William James's theory of emotion postulates that the bodily reaction triggers the emotion, not the other way round. Could we interpret the 'dancing plague' as an unconscious, pathological attempt to use dance (physical movement) symbolising joy and well-being - as a means of changing personal circumstances (mood)?

Sartre's view of emotions suggests something of the sort. I deal with it briefly, not only because emotion is so intrinsically part of human existence, but also because our thoughts about emotion reflect a desire to apply its energy and magic positively in our understanding of the world. In a sense, positive emotion is also an attempt to restore magic to a disenchanted world. Emotion in the form of affect adds value to our lives. Negative emotion, on the other hand, can be frightening and shameful, and is relegated to standard behaviourist truisms about an over-structured world. The world today is dominated by rationality, whilst emotion functions at a subconscious level. We know it is there and influences us, but it should not be expressed outside the social space that convention allows it to.

Sartre sees life as more than simply perception. We draw a $\mathrm{map}^{4}$ of the world for ourselves. This hodological map shows the routes to be followed to attain whatever goals we set ourselves. But there are many obstacles on the way, and often we convince ourselves that we reach our goals in magical rather than natural ways. Dreaming of winning the lotto is akin to magic. We try to shape the world according to our dreams; if we fail to do so, we resort to a coping mechanism, albeit negative in the sense of defeat and capitulation:

We do not take flight to reach shelter: we flee because we are unable to annihilate ourselves in consciousness. Flight is fainting away in action: it is magical behaviour which negates the dangerous object with one's whole body ... (Sartre 1962:67)

4.The map metaphor also features prominently in Spinoza's and Damasio's descriptions of emotion. Damasio (2003:201ff.) emphasises the body maps that descriptions of etion. Damasio (2003:201ff) emphasises the body maps that from the by 's from the body's special sensory probes' (Damasio 2003:214). That accounts for his fascination with Spinoza. 'The real breakthrough, as I see it, regards Spinoza's notion of the human mind, which he defines transparently as consisting of the idea of the human body' (Damasio 2003:211)
Of course, Sartre is wrong, at least from an evolutionary perspective. ${ }^{5}$ I may be able to change the world through emotional acts, and fainting is perhaps one of the less common consequences of intense emotion. But what is intriguing is the link between emotion and magic and its place in our self-evaluation.

Human emotion is a powerful common denominator that transcends temporal, cultural and ethnic boundaries. Our earliest ancestors' fears supposedly helped them to survive, and the domestication of temporal forces is said to have taken place by embodying them anthropomorphically in art and religion. One of the very first rational acts that accompanied emotions (of which fear was probably the foremost) was most likely the application of causality. When forces and events are personified, the additional factor of motive arises, which is humanly comprehensible and manipulable. Hence the primitive notion of bargaining with the gods (the do ut des principle). Causality and the possibility of influencing causal forces were part of human life from its beginning. Evolution contributed to the process by providing us with hermeneutic keys; these function at the emotional level. I cannot read people's thoughts (especially not in pre-linguistic times), but I can read their emotions in their facial expressions. That was the principal sign available to us prior to speech, which determined our behaviour towards others. Cardinal emotions such as fear and anxiety usually triggered specific actions that one could foresee and react to timeously.

\section{Are emotions changing?}

Although emotions are biologically rooted, cultural context largely provides the trigger that activates emotion. The things that embarrass us, make us happy, that we fear, et cetera depend on our cultural context. While emotions are largely subconscious and autonomous, our subconscious, our 'biology', is culturally informed regarding things that benefit or endanger life. 'Brainmaps' comprise both 'bodymaps' (see Damasio 2003:195-197) and cultural maps (habitus), on which autonomouts processes are based. So our probing of emotion should allow for both bottom-up biological processes and top-down environmental processes; these pertain to our bio-cultural world. Our biology provides the emotional 'mechanisms' and our culture co-determines the trigger mechanisms and paradigms of emotional expression. The biological apparatus is given, but cultures change; examples are the influence of impersonal systems in an increasingly 'automatised' society, and the impact of cyber-space and the concomitant virtuality. ${ }^{6}$

Intriguing examples exist at grassroots level. The vocabulary used to express emotion has changed in recent years. A study conducted at the universities of Bristol, Sheffield and Durham

5.Intense emotion is unplanned and not based on certain strategies, as Sartre would have it. 6.These factors often influence emotion indirectly. Riis and Woodhead (2010:175)
cite 'Foucault's account of internalized forms of social alienation' and 'Habermas's cite 'Foucault's account of internalized forms of social alienation' and 'Habermas's
account of the colonization of the "life world" of human relations by the logic of dominant systems'. 
used a Google database of 5 million digitised books to check the frequency of words that convey affect (mood words). The words were divided into six categories corresponding to the classical emotions (anger, disgust, fear, joy, sadness, surprise) (see Acerbi et al. 2013).

The researchers found that moods followed broad historical trends, including a 'sad' peak corresponding to the Second World War and two 'joyous' peaks, one in the 1920s and the other in the 1960s. More recently there has been a 'sad' period, starting in the 1970s, with an increase in 'joy' in the last years of the dataset. Interestingly, the First World War does not seem to have brought any special change in mood words.

Overall there has been a decline in the use of mood words over time, which underlies the distinct increase in emotional word usage in American, as opposed to British, books in the last 50 years. Notably, the mood of fear, which declined throughout most of the early 20th century, has increased markedly since the 1970s, in contrast to the continued decline of other moods. The researchers also found that American English and British English have diverged stylistically since the 1960s. American English has become decidedly more 'emotional' than British English in the past 50 years.

One might assume that literature is a fairly accurate reflection of the emotions of a large group of people who are influenced by the same environmental factors. ${ }^{7}$ But as society and its institutions change, morality shifts and religion starts playing a different role, and the way that emotion is experienced and expressed is likely to change as well. Rorty (2004) writes:

Social institutions provide the models for the feelings of responsibility and accountability; they set norms for the tenor of social interactions, finely attuned for status and power, formality or intimacy, empathically tactful or aggressively confrontational. They form the patterns and the habits of aggression and cooperation that are exercised in generating and resolving ordinary conflicts. (p. 277)

If institutions and many other relevant influences change, one would expect the language and manifestation patterns of emotion and the mechanisms that trigger it to change as well. These include the emotive metaphors used and how they fit into the causal schemata that we fabricate to fit our view of the world. These words, metaphors and schemata in their turn co-determine what triggers our emotion.

\section{Alternatives to reductionist models of emotion}

Can something as complex as emotion be condensed into a single model? Opinions on physicalist models differ, but the real question is whether emotion subsists in more than

7.In 2004, Paul Gilroy argued that Britain was suffering from 'post-imperial melancholia'. He cited it as an example of the same affect elevating the sentiments of millions of people in as antiments of millions of people in a given era to something like 'an affected national present tense' (Wetherell 2012:7, 16). Such a national present tense (consciousness) may even expand into a global present tense, for example when the consequences of natural disaster affect everybody. Every era, ethnic group, society and interest group has an entire string of traditions, vocabulary, rites and rituals that express the value and sentiments that are prevalent at the time. simply autonomous physicalist reactions, and if so, how it should be defined and identified.

\section{What is an emotion?}

As is thought, emotion is embedded in the relational nature of life. Neither thought nor emotion is conceivable without relations with other people and things. What makes emotion fascinating, and even mysterious, is that it reflects something of the biological and evolutionary 'intervention' peculiar to one's way of handling events. While the 'rational self' is still trying to clarify the situation, the 'frightened self' takes over. In a heated argument, the 'controlling self' is interrupted by 'another self' losing its temper. This biological side of life and the way it intervenes in our attempts at asserting our presence in real-life situations is expressed in metaphors such as 'She was seized/overcome by emotion'; 'He couldn't restrain his emotions'; 'His life is governed by passion'; 'Your actions are dictated by emotion'; 'I was overwhelmed'; 'She was swept off her feet' (see Kövecses 2000:51ff.,61, 72).

The loss of control is expressed in metaphors that refer to it as insanity, magic, rapture and a divided self (Kövecses 2000:43, 110). Emotions are conceived of as autonomous forces that influence and/or overwhelm us. It is a moot point whether it is indeed emotion if it is regulated and controlled. Emotion is actually something that overcomes us. Affect, however, refers to something 'extraneous' that touches and influences us. If our model were to overemphasise reason, judgement and decision-making, emotion in the original sense of the word would no longer feature. A phenomenon has an emotive structure only if it could not exist or manifest itself without emotion. Hence, diverse phenomena may be emotive - primarily emotion as such, but many indirect sensations as well (Snævarr 2010:319).

Damasio (2003:43) distinguishes between background, primary and social emotions to accommodate various forms of emotion. Riis and Woodhead (2010:20) make the following practical distinctions: '..."passions" conveys the power of emotions, "feelings" their embodied aspect, "sentiments" the way they relate to character and education, while "affect" suggests their passive and reactive dimensions.' Our analysis of affect will show that it is actually more complex than just passivity and reactivity.

For Griffiths there is no such thing as a distinct, particular class of emotions. He discerns three types of phenomena that qualify as emotion: affect program responses; irruptive motivational states; and disclaimed action emotions (Snævarr 2010:297). Affect program responses are primitive, swift and stereotropic (such as fear); irruptive motivational states and disclaimed action emotions are cognitively higher emotions that are in fact long-term, rational behavioural patterns; they include shame, jealousy and loyalty (Snævarr 2010:297). Disclaimed action emotions are conventional social constructs of which we are not even consciously aware.

There are so many distinctions, definitions and classifications that every author has to specify what is meant by a particular term. But are we speaking about the same phenomenon? Are 
the various aspects of human emotion, mood, judgement, et cetera not too complex to be accommodated in single, reductionist models? 'It is idle to compare and evaluate these various theories of emotion as if they were competing accounts of the same phenomena' (Rorty 2004:270). Wetherell (2012:115) refers to affective practices, comparable to Bordieu's habitus, where affect is unreflective and nonconscious, 'never planned, self and other regulated, narrated, agentic and negotiated'.

The traditional six emotions defined by Darwin may be too restrictive to capture the full range of emotional experiences. Ever since the publication of his The expression of the emotions in man and Animals in 1872, the evolutionary aspects of human and animal emotions have been in the spotlight. The accent was on the function of emotion to promote adaptation and survival of the species.

This is the basic, physicalist model of emotion. ${ }^{8}$ Its main features are: emotion is usually short-lived; it is automatic; it is evoked by a trigger mechanism (arousal); it is determined by the unconscious; and it is strongly associated with facial expressions and bodily movements. It is directed to an (emotional) object and includes judgement that may change when new information becomes available. 'Emotion so understood is a brief, preconscious, precognitive, more or less automatic excitation of an affect program' (Solomon 2004:78). Wetherell (2012) is critical of the basic orientation underlying the physicalist slant:

The basic emotions paradigm that dominated the psychobiology of affect was a deep investment in the idea that emotion routines are programmed, that affect templates are innate residues of archaic pasts, and that the 'colour wheel of affect' falls into relatively discrete patterns. (pp. 17-18)

Physicality is only one side of the coin, which we may describe as the 'hardware'. The 'software' remains determined by the historical era, cultural and social factors. Every era has its own rules and conventions that stipulate what we should be ashamed of, what embarrasses us, what we fear and what makes us happy. Even though emotions operate mainly at an unconscious level, that level is nourished by the life world in which we are raised. So we are affectively programmed and, although the programs run automatically, every generation contributes to them. 'The basic emotions thesis distils types from the flux of everyday experiences yet ultimately it is that flux across all cultural and social situations that must be explained' (Wetherell 2012:43).

\section{The basic emotion model}

In 1884, William James published 'What is an emotion?', in which he maintains that it is not emotion that causes the bodily response, but that the body's response (flight) in fact

8.In the 21st century many psychologists and philosophers hypothesise that emotions, or at least the 'basic' emotions, are 'affect programs', essentially hardwired and evolutionarily derived complexes of nuscular responses, with accompanying feelings, of couse. An emotion is for the most part an unconscious or at least not necessarily conscious physiological process, which may or may not still serve an evolutionary function but does not involve sufficien 'cognition' to be rational in any meaningful sense (see Wolpert 1999:115). evokes the emotion (fear) (James 1884:188-205). James's view is noteworthy in that it implies that emotional feelings are the consequence rather than the cause of emotional behaviour. The process is as follows: an arousing event occurs (e.g. I stumble). Internal changes follow: my heart pounds, my skin tingles, I perspire. I experience an emotion: I am startled. James derived his basic idea from Darwin, who wrote:

The free expression by outward signs of an emotion intensifies it. On the other hand, the repression, as far as this is possible, of all outward signs softens our emotions. He who gives way to violent gestures will increase his rage; he who does not control the signs of fear will experience fear in a greater degree and he who remains passive when overwhelmed with grief loses his best chance of elasticity of mind. (quoted in Walton 2004:xv-xvi)

Physical responses such as heart palpitations, deep breathing, adrenalin secretion and perspiration can be triggered by diverse emotions, and are hence not themselves responsible for the emotion. That means we have to consider factors other than only bodily changes: why is it that the same changes may arouse different emotions?

Regarding physiological factors, the number of physical processes involved, of which emotional reactions are but one, usually go unnoticed:

Emotions for Damasio, are simply the 'top end' of the broad range of body processes involved in homeostasis which range from immune system activity, metabolic activity and simple reflexes, to experiences of pain and pleasure, to drives and motivation, and then to conventional emotions. (Wetherell 2012:30)

What Damasio (2003:205) describes are simply physiological processes: '... the brain brings along innate knowledge and automated know-how, predetermining many ideas of the body.' This explanation suggests dualism:

The brain commands the body to assume a certain state and behave in a certain way, and the ideas are based on those states and body behaviors ... They are ideas of body actions, yet those body actions were first dreamed by a brain that commanded them to occur in a corresponding body (Damasio 2003:205)

Contrary to Damasio's approach, Wetherell (2012) writes:

An affective act is not like an instinct or a fixed action pattern. It does not seem to be the case that an 'emotionally component stimulus' or emotional inducer hits a trigger in our brains, with our minds playing catch-up, forming an idea of what the body is doing in order to produce feeling and a mental description. (p. 45)

It is difficult to avoid dualisms. In our minds, unconscious, involuntary physical processes inevitably contrast with our conscious, intentional side. It is my body, my emotions, my ideas, but it is also I who objectify and critically scrutinise them. Damasio (2003:206) tries to preserve the unity. He relates mind to the entire body, not just the brain: 'The brain's body-furnished, body-minded, mind is a servant of the whole body.' But we are unaware of most of these processes.

A problem is that Wetherell wants to come to grips with all the social, cultural and interpersonal influences that enter into emotion. That is unavoidable to ensure a clear focus on the affective turn. But Damasio rightly observes that 
many of these processes are autonomous and unconscious, which limits our grasp of them. ${ }^{9}$ Again we have a top-down approach as opposed to the physiological emphasis on bottom-up processes.

\section{Appraisal model: Role of cognition}

Reason was seen traditionally as the antipode of emotion. Pascal speaks of 'reasons of the heart that reason cannot fathom'. ${ }^{10}$ But reasons of the heart presuppose cognition. Affect has its own reasons that 'set me in motion', but they function at a different level than do rational ones. In the heat of the moment, emotions may be aroused that correspond with whatever triggered them. But an emotional 'outburst' may also build up gradually and eventually manifest as an overreaction. It may embarrass me because, seen as a response to an individual incident, my reaction may appear excessive if one disregards the pent-up frustration that might have been building up over many years.

Schachter and Singer ${ }^{11}$ propose a two-factor theory that, to experience an emotion, one needs both physiological arousal and cognition. They argue as follows: Firstly, if we are aroused inwardly, say by adrenalin, and we do not know the cause, then we seek a reason. We label our feelings as happy if people around us are in a party spirit, or angry if they are trying to pick a fight. Secondly, if we know we have been injected with adrenalin, we do not need to label our feelings, believing that they are neither particularly happy nor sad. Thirdly, if someone is in a happy situation but is not physiologically aroused, then they should not feel any emotion; the same applies to a sad situation. Schachter and Singer's findings confirm the foregoing assumptions, which in turn confirm the connection between emotion and reason. Circumstantial suggestions (appraisal) determine the course of an emotion. The problem is that we are applying two sets of values: on the one hand, at a naturalistic level, the brain chemistry of emotions; on the other, at a cognitive level, an emphasis on conceptual analysis. Yet the operation of the brain presupposes both (see Snævarr 2010:298).

The appraisal model accentuates the role of human rationality (judgement) in emotion. Emotions are not a purely reflexive response to objects or events. They are products of the individual's meaningful interpretation of an object or event. Animals, too, show signs of appraisal in their manifestation of emotion. Solomon (2004:82-83) writes as follows about emotion and appraisal:

9.Sartre (1962:55) sharply criticised the notion that emotion is governed by the unconscious: 'If consciousness organizes emotion as a special type of response adapted to an external situation, how does it manage to have no consciousness of this adaptation?'

10.See Tillich (1951:86), who points out that the emotional element in music opens up a dimension of reality that is not accessible to mathematics. Communion is no less rational than law, but the emotional element in communion opens up a dimension of reality that is inaccessible to law. One can take Tillich's idea further. An event a the personal level that hardly affects me at all, may overwhelm someone else. That is because the filter or lens through which we experience the event may differ, just as music/communion and mathematics/law differ in Tillich's example.

11.As far back as 1962, Schachter and Singer showed that the same physical symptoms may accompany different emotions. Test persons injected with adrenalin experienced different emotions depending on positive or negative influencing before the drug took effect. The emotional feeling (induced by adrenalin) is not before the drug took effect. The emotional feeling (induced by adrenalin)
confined to only one emotion, but can galvanise quite different emotions.
... they [emotions] are about the world (including oneself in the world). They are episodic but possibly long-term processes as well. They must span conscious and non-conscious awareness... They must involve appraisals and evaluations without necessarily involving (or excluding) reflective appraisals and evaluations. They must stimulate thoughts and encourage beliefs (as well as being founded on beliefs)... and they must artfully bridge the categories of the voluntary and involuntary. (pp. 82-83)

Because emotion differs so greatly from mood (e.g. it may be much more intense and is short-lived), they are not in the same category. Affect affords more differentiated insight into the 'emotional' side of human beings, into our embodied existence, than an exclusive focus on basic emotions does.

Stocker (2004:136ff.) shows how emotion and desire enhance intellectual activity. The drawback of a cognitive slant on emotion is that it does not acknowledge the link with bodily feeling and reaction and the focus on an object of emotion (Goldie 2004:91). Neither must we forget that emotions can be misleading: '... how profoundly and systematically our emotional feelings can mislead us ... can distort perception and reason' (Goldie 2004:91, 102). We can be emotional without realising it and without being aware of its negative effect on our perception and reasoning (Goldie 2004:102-103). It is probably this suspicion (that emotion is not logical and objective) that led to the rejection of any connection between emotion and intellectual activity between emotion and epistemology. Reason has become so objectified and void of a subject, extraneous and antithetical to human beings, that it retains no trace of emotion (subjectivity). The common view is that theoretical reason is non-personal and emotionless (Stocker 2004:139).

\section{The affective turn}

According to Thomas Dixon (quoted in Wetherell 2012:95), affect has been progressively secularised since the 19th century. It has been separated from religious categories and sense-making and is increasingly regarded as a psychological phenomenon. Until the 19th century, it was regarded as movements of the soul and affections, which in their turn were distinct from passions and moral sentiments. The notion of affect as a movement of the soul (whatever that may be; it has a religious element) was naturalised in the 19th century:

Emotions came to be seen as involuntary, body-based, entities which moral effort and judgement worked upon. This superseded the notion that affect might be a moral act in itself, or a visitation from a supernatural agent. (Wetherell 2012:895)

The affective turn expands our understanding of emotion to include judgement, thought and appraisal. According to this approach, emotion influences us every day:

We are always already within complex patterns of social and symbolic relationships, and 'emotion' is a name we give to the multidimensional processes by which subjects navigate and negotiate within them. We 'feel' our way through life in an embodied engagement ... (Kövecses 2000:53)

That would imply that we are governed at all times by one emotion or another. We know we are always in some mood, 
which is by and large 'neutral', so we are unaware of it. By analogy with emotion, unconscious, autonomous bodily processes may play a major role in our moods. In day-today living, a certain valency is attached to experiences, sense perceptions and interpersonal relations that all combine to determine our moods.

The affective model is open, sees emotions as dynamically mobile and includes many other human faculties. ${ }^{12}$ This approach cannot be dissociated from basic emotions, or be reduced simply to mood or motivation. Motivation in itself implies emotion in the sense of the weightiness, resolve or seriousness that one associates with a challenge:

So too, there are claims - made by Kierkegaard, Heidegger and others - that without certain forms of care and concern, we would not 'parse' the world at all, or much less than we do; that without such care and concern, nothing would be salient, intellectually or otherwise. (Stocker 2004:135, 139)

Probably emotion is not the right word for it, but terms such as 'desire', 'motivation' and 'concern' are only properly understood if we allow for their emotional side. Ernest Schachtel (quoted in Stocker 2004) writes:

There is no action without affect, to be sure not always an intense, dramatic affect as in an action of impulsive rage, but more usually a total, sometimes quite marked, sometimes very subtle and hardly noticeable mood, which nevertheless constitutes an essential background to every action. (p. 137)

The same view is adopted by existentialist philosophers (Heidegger, Merleau-Ponty, Sartre); it concerns human existence at a personal and a social level. Here emotional judgements are seen as ways in which we are involved in the world (Solomon 2004:87). ${ }^{13}$ 'Affect is always "turned on" and "simmering", moving along, since action is continually embodied' (Wetherell 2012:12). We are never free from affect. We are always in some sort of mood. Whereas emotions can be captured in specific words such as fear, joy, shame and the like, one would need to search an entire dialogue to identify affect. It would also permit finer differentiation that would enable us to indicate the specific affective valence. Thus a conversation or event that seems to have no strong emotional value in the traditional sense of the word may be heavily loaded affectively.

Wetherell (2012:10) refers to affect as expressed in 'feeling practices', by which she means:

... people's allegiances and investments, and the activities of categorising, narrating, othering, differentiating and positioning ... A practice approach focuses on processes of developmental sedimentation, routines of emotional regulation, relational patterns and 'settling'... The individual is a site in which multiple sources of activation and information about body states, situations, past experiences, linguistic forms, flowering thoughts, etc. become woven together. (Wetherell 2012:10, 22)

12.According to Wetherell (2012:12), the dynamic, mobile nature of affect emerged with the rise of relational and process ontologies and process methodologies in social theory. Examples are Actor Network Theory, feminist technoscience, cultural geography, the work of Deleuze and a revival of Whiteheadian metaphysics.

13.The intentionality in my encounter with the world is already affectively laden and manifests itself in an attitude of intellectual courage, intellectual generosity,
liberality and intellectual modesty. Stocker (2004:140) considers intellectual interest and excitement to be examples of concern and desire.
A new turn in reflection on emotion is called for. If only basic emotions accompanied by manifest physical responses are regarded as emotions proper, where does it leave the host of other feelings that are part of our lives? Does our state of mind depend wholly on moods/affects and are 'genuine' emotions unimportant? Rorty (2004) expands on this point:

Where does distrust fit? Is greed a motive, a character trait? Is joy a mood? A feeling? Is pride a character flaw, a sin, a social construction (whatever that is)? Is benevolence a condition of the will? A feeling virtue? Is love a passion, an emotion, a sentiment? And schadenfreude? A sense of devotion, dedication, or ambition? Japanese amae? ${ }^{14}$ Awe? Piety? Respect for human rights? What about a sense of vulnerability? Aesthetic delight? Moral indignation? (p. 269)

It is important to distinguish between a cognitive element in affect, and affect experienced as the dominant component. When I am aware of a powerful affect, do I feel any different from when I am simply reflecting neutrally on something? It depends on what affective augmentation does to our thoughts and actions. The assumption is that, in that case, affect differs from a primary emotional outburst in that it lasts longer and is accompanied by far more reflection. Clearly it is difficult to measure the difference that affect makes to thought processes. The best way to establish that is to look at language.

\section{Emotion and language: Narrative and metaphor}

Firstly, we must distinguish between language used to express emotion and affect that we experience directly on the one hand and, on the other, language in an artwork (e.g. poetry) that deals with emotion. Because a poet is familiar with emotion and is affected by things, we speak of a 'compulsion' to express it poetically. The same applies to prophets (e.g. Jeremiah), the visual arts and music. One can rationalise affect and reflect on it academically, but that is different from expressing it artistically. In that respect, affect is almost a separate human faculty alongside reason, although it is by no means irrational. Aesthetics makes no sense without affect, and the enigma is in fact that we tend to understand affect indirectly, symbolically and metaphorically, veiled in images, sound or colour.

Language is the link between cognition and emotion simply because thought is articulated in language and emotion is elucidated post hoc in language. 'Articulations are like interpretations in that they are attempts to make clearer the import things have for us' (Snævarr 2010:315). In our attempt to clarify emotions, we are in a sense their co-authors, provided we believe our own interpretations.

Language is not the only medium to convey emotion. Music, ${ }^{15}$ scenery, a particular place, a fragrance, can express affect as well, but language is the most important. We cannot help talking about emotions that moved us. Our versions

14.Amae is a concept developed by Japanese psychoanalyst Takeo Doi to describe the human need to be in good favour with others. Amae refers to parents indulging their child. In this regard, the parent-child relationship is idealised.

15.Johann Mattheson (1681-1764) devised an affective 'ladder' for baroque music and described 20 affects that can be expressed in music. 
will differ and each person's emotional imprint will be distinctive. ${ }^{16}$ The emphasis on language (see Gerhard Ebeling 1960) is inconceivable unless a particular affect is associated with the interpretive event. But events have to be understood in diverse senses and at different levels. A language event is more than the intra-linguistic processes that occur: it includes reality with all its affects as the domain of life.

Our reflection on, and articulation of, emotion sometimes confronts us with ourselves as strangers. What we are trying to fathom is our emotion. We rationalise an action triggered by an emotional reaction, as we do when we lose our temper or (over)react to a threat. But it is not always a simple process. When we talk about our emotions and the accompanying affects, there is no guarantee that our interpretations are correct. Does my verbalisation of my feeling seek to analyse the emotion critically, or must it simply affirm the emotion (uncritically)? When I am jealous or envious, I fabricate reasons that reinforce the feeling - self-critical correction is less common.

We rarely fail to talk about emotionally significant events. Talking about an emotion makes all the difference: 'If I express how I feel in words or pictures or bodily enactment, I feel differently, and thereby change my relations with myself and other people and things' (Riis \& Woodhead 2010:45). Over the years, we establish an emotional vocabulary, with a preference for emotive metaphors and expressions. We tell biographical stories about the worst fright, embarrassment, fear that we ever experienced. Virtually every biblical narrative has a pronounced emotional component. Such emotively laden tales are often elevated to paradigms appropriate to the personal biographical anecdotes. They culminate in emotional regimes. ${ }^{17}$

\section{Narrative and emotion}

If we concede that judgement, evaluation and reflection are concomitants of affect, how do reflection and affect influence each other? Is reflection more logical when it is less affectively coloured? It is not readily measurable and the relation between affect and narrative may be more illuminating.

Emotions are recounted and the accounts have a narrative structure. They have a plot, a beginning, a middle and an end. The emotion is conveyed by the narrative and expressed in its terms. Narrative structure is the mortar that combines feeling, faith, actions and personal traits in an emotional whole (Snævarr 2010:323). The narrative constitutes emotion. Hence it is a cyclic movement, ${ }^{18}$ in which emotion is not only the consequence of the narrative but actually evokes emotion.

16.Emotions are highly subjective and are first-person experiences: 'Thus, there is no equivocation in meaning between the first-personal and third-personal with regard to emotions' (Snævarr 2010:297).

17.These allow considerable scope for change and variation: 'Emotions are neither static nor given; they tend to change; the elements in them can come and go or wax and wane' (Snævarr 2010:323)

18. One could call the process in which emotional memory makes me recall dramatic past events that distress me all over again, an affective cycle. The events are linked with new associations and ideas I never had at that time, and the modified narrative becomes part of my adapted emotional memory (see Du Toit 2013 for the ongoing adaptation of memory).
However, the narrative element often leads us to wrong conclusions, makes us ascribe events to the wrong causes and perceive them in a subjectively biased perspective. Unrelated things are linked to each other, unjust and bad motives are attributed to others' words and actions, and nonexistent direct causal connections are established. The aim of the narrative is in fact to express the indignation, humiliation, fear, jealousy or whatever feeling we may have. At the same time, our own, often irrational or exaggerated, reaction is justified. In such cases, affect has a negative effect on logical reason and fair judgement.

Emotional metaphors are equally powerful. They can serve as a bridge between cognition and emotion. We use metaphors to describe and understand emotion. Using standard metaphors for an emotionally charged situation helps to identify the emotion because there is a firmly established conventional link. Metaphor has always been the best way to link apparently unconnected things. In particular, metaphors build bridges between the world of nature and the mental world. Why should the relation between emotion and cognition be any different? Snævarr (2010) points out:

Metaphors possess aboutness that cannot be reduced to neuronal and bodily activities... To make matters worse, trying to locate metaphors in our neuronal processes is like trying to understand music by analysing the physical structure of airwaves that 'carry' music. (p. 124)

Conversely we must acknowledge that many of the links we establish between cognition and physicality, between emotion and judgement, between inner world and the outside world of objects, are no more than metaphoric. It is remarkable how many of the metaphors used to convey emotion derive from nature.

\section{Religion and emotion}

There are no specifically religious emotions. Any emotion can be religiously coloured. 'What makes an emotion religious is, therefore, the fact that it occurs within a religious context and is integral to its social and symbolic relations' (Riis \& Woodhead 2010:54). In his Varieties, James writes that genuine religious emotion "turns out to be the opposite of "morbidmindedness": it is a "mystical" state of emotional expansion that embraces reality in a sentiment of loving acceptance and felt significance' (see Riis \& Woodhead 2010:60). The problem is that this view is too individualistically oriented and does not pay sufficient attention to the objects that evoke religious emotions and the resultant social relations (Kövecses 2000).

Without the basic emotions, religion makes no sense. The principal Christian doctrines, for example, cannot be understood unless one allows for basic emotions such as fear, shame, happiness and the like. But within that context, the basic emotions do not function on purely evolutionary principles either, because Christianity itself dictates the conditions for fear, ${ }^{19}$ shame or joy by assigning them a particular purport.

19.The abuse of human emotion by some religious groups has often been pointed out. Walton singles out the role of religion in instilling Angst: '... The concept of Angst - anxiety ... has its roots in Christianity, in its insistence that all human conduct was subject to bottomless accountability. This is itself a modification of conduct was subject to bottomless accountability. This is itself a modification of
the vengefulness of Yahweh' (Walton 2004:10). In his view, religion is founded in fear: '... we can see primitive fear as the engine of all religious 
Damasio (2003) observes that in a world without emotion and feelings:
... there would have been no spontaneous exhibition of the innate social responses that foreshadow a simple ethical system - no budding altruism, no kindness when it is due, no censure when censure is appropriate, no automatic sense of one's failings. (p. 157)

But without basic social emotions and feelings, there might have been no religion in the first place. Feelings were probably necessary to substantiate ethical behaviour ${ }^{20}$ long before people consciously defined intelligent norms for social behaviour (Damasio 2003:160).

To characterise emotion as religious, requires some reference, albeit indirect, to transcendence (God). I do good to others in obedience to Christ, or I plant a bomb out of commitment to Allah (Roberts 2008:493). Some Christians see emotion as a result of the work of the Spirit. Christian hope is a religious emotion because it includes faith in God's involvement with our future. Damasio (2003:284f.) sees spiritual experiences as biological processes at the supreme level of complexity that have beneficial results for the individual, such as harmony, equilibrium and nourishment.

Religion without affective appeal is doomed to extinction. Has Christianity lost its affective appeal? Is the upsurge of Pentecostalist groups in Africa and Latin America attributable to the (ab)use of emotion? It is not that simple. Overall, late modernity has seen growing resistance to any externalisation of emotions that may be seen as 'inappropriate' and 'embarrassing'. Most religious communities have adapted their emotional 'programmes' to accommodate their members' specific needs (see Riis \& Woodhead 2010:203).

In Protestant tradition, affect, reason and faith went hand in hand. Hegel puts it aptly. The doctrines of the Christian church are the main source of the arousal of feelings, '... but feelings that proceed from the teaching of truth, from representation and from objectivity, and are, therefore, genuine feelings for the first time' (Hegel 1985:151). This should be seen against the background of the churches as repositories of supreme, ultimate truth, which in the mode of revelation touches people's innermost depths, represents the very ground of their existence, and determines their happiness and their future. In addition, the mystical dimension and the passion, which feature in Christianity in all sorts of ways, cement the connection between faith and affect. This was a hallmark of traditional Protestantism in South Africa. ${ }^{21}$

But we all know that the concept of eternal truth has been whittled down, technology has cast out ignorance and

(Footnote 19 continues...)

belief ... [emotions] are the bedrocks on which much, if not all of our social and cultural lives rest' (Walton 2004:xix)

20.An example is that law, too, may be emotionally rooted: according to the Scottish Enlightenment, law is grounded in emotion, especially positive emotions such as sympathy that forms part of human behaviour (see Damasio 2003:320). If that applies to law, it applies all the more to theology.

21.We increasingly see in this country what has already happened in Europe, namely that people are sceptical about church doctrine, although they still practise its rituals on major occasions such as birth, marriage and death: 'They may not believe in what the symbols point to, but they understand the value of the emotions that in what the symbols point to, but they understand the value
are evoked by the symbols' (Riis \&Woodhead 2010:190). fear, postmodernity has introduced an ethos of the multidimensionality and ephemerality of all things and, to many people, science has ousted religion as the sole reliable expositor of the world. The traditional 'vehicles' of emotion - belief in miracles, fear of hellfire, eternal punishment, damnation - have largely been repudiated..$^{22}$

It becomes increasingly difficult to sustain an emotional regime based around [sic] the symbols of a strict deity judging a sinful humanity. Even conservative theologians are pressed to adapt their regimes to the values and emotions that predominate in democratic society, and even the strictest religious regimes are modified and loosened to make some accommodation to the changed emotional environment (Riis \& Woodhead 2010:200)

Recent years have seen the mushrooming of alternative forms of spirituality that mark a turn to personal emotional discovery, experience and enactment. The movement is too broad to allow a uniform approach. It ranges from forms of New Age spirituality to intellectually oriented concern with societal and environmental issues, Eastern religions, meditation and mysticism. The leader and the small group or network are committed to the spiritual 'path', the personal growth of each of its members (see Riis \& Woodhead 2010:203). But the accent on personal insight and spiritual experience is coupled with a distinctive focus on reality as manifested, for example, in eco-spirituality. It may also concentrate on aspects of the new cosmology or societal problems such as poverty and the promotion of sustainability. A common denominator in the new spirituality is a search for and expression of affect accompanied by reflection but not inhibited by dogma.

Humans' relationship with the godhead is indisputably affectively charged. Veiled affect is more appealing than raw emotion and, for some reason, human beings are driven to express things that move them profoundly in art. Above all they express them religiously. But does that justify the (Protestant) doctrine of God? God's hiddenness, our indirect symbolic and metaphoric access to God, his paradoxical remoteness and closeness, love and fear, grace and judgement - should all this be viewed in the light of human affect? Grace, judgement, sin and hope are affectively charged and may reflect the human will to relate affect to their deepest ground, ultimate questions and absolute love. The metaphysical features of the doctrine of God are acknowledged by theologians, but if this metaphysics is not based on intellect alone but more especially on affect, it touches the very core of our humanity and cannot be conjured away by some theological paradigm shift.

Anthropologically, then, religion may be defined as the mode in which human beings express their deepest affects. A sense of security, community, ${ }^{23}$ uncertainty, fear, longing, guilt, forgiveness, generosity and the like are key elements of every religion, and are meaningless unless their affective

22.'Thus, historic Christian symbols illustrate themes such as evil, temptation, sin fear or hell, and diabolic power. But such themes clash with the contemporary emotional agenda that places more stress on love, forgiveness, mercy, compassion, peace, and joy' (Riis \& Woodhead 2010:195).

23.Scholars are critical of the reduction of affect to the limbic system and especially the so-called mammalian brain. Yet mammals are gregarious, which also links them emotionally (also see Wetherell 2012:43). 
support base is taken into account. When our equilibrium is disturbed, it evokes powerful emotions. Religion restores equilibrium (harmony with ourselves and others) by anchoring it affectively in rites, symbols and narrative.

\section{Conclusion}

The unity of a human person - not only unity of body and mind, but also of brain and thought, emotion and judgement, affect and action, conscious and subconscious, language and emotion, emotional inner and outside worlds - should be preserved as far as possible. The idea is not to read emotion into everything, so that the very banality trivialises it. We are emotional no less than rational beings, and our delineation of human faculties does not necessarily coincide with biological boundaries. To understand human behaviour, we must take account of all these factors: the unity of the organism, interaction with the world, the connection between the conscious and the subconscious, and the mutual influencing between reason and emotion, and reason and affect.

All this multiplicity and complexity make it difficult, if not impossible, to get a firm grasp on the emotional aspect of our humanness in which we can act meaningfully, be inspired, wounded and healed. Maybe that is as well. Once everything 'sacred' has been sacrificed to reason, logical reduction and ineluctable biological laws, one of the profoundest emotions - associated with wonderment, mystique, mysticism - is forfeited and life loses its allure. Then we are doomed to carry on dancing without joy, to laugh without delight, to worship without faith. Then symbols have no meaning, reference (signifiant) has no referent (signifié) and emotion no affect.

\section{Acknowledgements Competing interests}

The author declares that he has no financial or personal relationship(s) that may have inappropriately influenced him in writing this article.

\section{References}

Acerbi, A., Lampos, V., Garnett, P. \& Bentley, A., 2013. 'The expression of emotions in 20th century books', Plos One, March 20, http://dx.doi.org/10.1371/journal.pone.0059030

Damasio, A., 2003, Looking for Spinoza: Joy, sorrow, and the feeling brain, Harvest, New York, NY.

Darwin, C., 1965, The expression of the emotions in man and animals, University of Chicago Press, Chicago.

Du Toit, C.W., 2013, 'Dynamically remembered present: Virtual memory as a basis for the stories we live', HTS Teologiese Studies/Theological Studies 69(1), Art. \#1937, 8 pages. http://dx.doi.org/10.4102/hts.v69i1.1937

Ebeling, G., 1960, Wort und Glaube I, JCB Mohr, Tübingen

Goldie, P., 2004, 'Emotion, feeling, knowledge of the world', in R.C. Solomon (ed.), Thinking about feeling: contemporary philosophers on emotions, pp. 91-106. Oxford University Press, New York, NY.

Hegel, G.W.F., 1985, 'The consummate religion', in P.C. Hodgson, L.A. Berkeley (eds.), Lectures on the philosophy of religion, vol. III, n.p., University of California Press, London.

Hobbes, T., 1968, Leviathan, C.B. MacPherson (ed.), Penguin, Harmondsworth.

Hume, D., 1978, A treatise of human nature, 2nd edn., Clarendo, Oxford.

James, W., 1884, 'What is an emotion', Mind IX(34), 188-205.

Kövecses, Z., 2000, Metaphor and emotion, Cambridge University Press, Cambridge.

Lyons, W., 1980, Emotion, Cambridge University Press, Cambridge, New York, NY. http://dx.doi.org/10.1017/CBO9780511609244

Riis, O. \& Woodhead, L., 2010, A sociology of religious emotion, Oxford University Press, Oxford. http://dx.doi.org/10.1093/acprof:oso/9780199567607.001.0001

Roberts, R.C., 2008, 'Emotions research and religious experience' in J. Corrigan (ed.) The Oxford handbook of religion and emotion, pp. 490-506, Oxford University Press, Oxford.

Rorty, A.O., 2004, 'Enough already with "theories of the emotions"', in R.C. Solomon (ed.), Thinking about feeling: Contemporary philosophers on emotions, pp. 269-278, Oxford University Press, New York, NY.

Sartre, J-P., 1962, Sketch for a theory of the emotions, Methuen, London.

Schachter, S. \& Singer, J., 1962, 'Cognitive, social and physiological determinants of emotional state', Psychological Review 69(5), 379-399. http://dx.doi. org $/ 10.1037 / \mathrm{h} 0046234$

Snævarr, S., 2010, Metaphors, narratives, emotions. Their interplay and impact, Rodopi, Amsterdam, NY.

Solomon, R.C. (ed.), 2004, Thinking about feeling: Contemporary philosophers on emotions, Oxford University Press, New York, NY.

Solomon, R.C., 2004, 'Emotions, thoughts, and feelings', in R.C. Solomon (ed.) Thinking about feeling: Contemporary philosophers on emotions, pp. 76-88, Oxford University Press, New York, NY.

Stocker, M., 2004, 'Some considerations about intellectual desire and emotions', in R.C. Solomon (ed.), Thinking about feeling: Contemporary philosophers on emotions, pp. 135-148, Oxford University Press, New York, NY.

Tillich, P., 1951, Systematic Theology, Combined volume, Nisbet, Digswell Place.

Waller, J.C., 2008, 'In a spin: the mysterious dancing epidemic of 1518', Endeavour 32(3), 117-121. http://dx.doi.org/10.1016/j.endeavour.2008.05.001

Walton, S., 2004, Humanity: An emotional history, Atlantic, London.

Wetherell, M., 2012, Affect and emotion, Sage, Los Angeles, CA.

Wolpert, L., 1999, Malignant sadness: The anatomy of depression, Faber \& Faber, London. 